\title{
Evaluation and Effect of Microbial Inoculants for Production of Growth Hormones and Organic Formulations on Growth of Baby Corn (Zea mays L.) under Green House Condition
}

\author{
B. Latha ${ }^{1 *}$, M.K. Shivaprakash ${ }^{1}$, N. Devakumar ${ }^{2}$ and N. Mallikarjuna ${ }^{3}$ \\ ${ }^{1}$ Department of Agricultural Microbiology, UAS, GKVK, Bengaluru - 65, Karnataka, India \\ ${ }^{2}$ College of Agriculture, Hassan, UAS, GKVK, Bengaluru - 65, Karnataka, India \\ ${ }^{3}$ AICRP on maize, ZARS, V.C. Farm, Mandya, Karnataka, India \\ *Corresponding author
}

\section{A B S T R A C T}

A lab and pot experiment was conducted during 2017-2018 to study the evaluation and

\section{Keywords}

Growth hormones,

Microbial and organic

formulations and Baby

corn (Zea mays L.)

Article Info

Accepted:

15 September 2018

Available Online:

10 October 2018 effect of microbial inoculants for production of growth hormones and organic formulations on growth of baby corn under greenhouse condition. The research was conducted at Department of Agricultural microbiology, UAS, GKVK, Bengaluru. Bioassay was conducted for growth hormone production of GA, IAA and cytokinin. Among all the microbial inoculants Pseudomonas fluorescens produces highest growth hormones than other microbial inoculants. There were 16 treatments comprising all possible combinations of microbial inoculants along with nitrogen sources were laid out in complete randomized block design with three replications Gluconacetobacter diazotrophicus + Bacillus megaterium + Piriformospora indica + Pseudomonas fluorescens + Bacillus subtilis + Trichoderma harzianum +50 per cent of vermicompost and jeevamrutha as a single, triple inoculation and also as multiple inoculation and different plant parameters was recorded. In all the parameters were significantly higher with multiple inoculation compare to triple, single inoculation and control.

\section{Introduction}

Baby corn is the young and unfertilized ear of the corn (Zea mays L.) plant harvested when the silks have either not emerged or just emerged (1 to $3 \mathrm{~cm})$.

After 65-75 days of sowing the tender green ears of baby corn are obtained and the husked young ear is canned or consumed fresh and is a popular vegetable because of its sweetness and delicious taste. However the production areas are still confined to few countries, including Thailand, Indonesia, India, and Brazil.

Baby corn's contains $15-18 \%$ protein, 0.016 - $0.020 \%$ sugar, 0.6 - $0.9 \%$ phosphorus, 2 - 3 $\%$ potassium, 3 - $5 \%$ fiber, $0.3-0.5 \%$ calcium, 75 - $80 \mathrm{mg} 100 \mathrm{~g}^{-1}$ and ascorbic acid. In addition, it is rich in thiamine, riboflavin and folic acid, low calorie and high in fiber without cholesterol (Pradeep Kumar et al., 2004). 
Important groups of microorganisms like plant growth promoting rhizobacteria (PGPR) which includes nitrogen fixer's viz., Azotobacter sp., Azospirillum sp., Acetobacter sp. and Burkholderia sp. phosphate solubilizers viz., Bacillus and Pseudomonas sp. and phosphate mobilizers viz., Bacillus sp. etc., and arbuscular mychorrhiza viz., Glomus sp. and $P$. indica that actively colonize with plant roots and enhances plant growth and yield. They increase soil fertility by increasing the amount of available nitrogen, phosphorus and other minor plant nutrients, synthesized several different phytohormones that can enhance various stages of plant growth and also suppress soil borne pathogens by antagonizing them. PGPR and biocontrol agents are known to produce amino acids, vitamins and growth promoting substances like IAA, GA and cytokinin which helps in better growth promotion of crop plants (Ponmurugan and Gopi, 2006). Now-a-days, organic farming system is gaining importance in sustainable agriculture due to it's holistic approach which promotes and enhances agro eco-system health including bio-diversity, biological cycles and soil biological activities.

Organic farming provides balanced nutrition thereby taking care of soil health by improving physical, chemical and biological properties of the soil through nutrient cycling (Anon, 2008). Some of the potential sources of nutrients in organic farming are indigenous liquid organic manures such as beejamrutha, jeevamrutha, panchagavya, amruthpani, liquid biodigester, biogas slurry, cow urine and vermiwash etc., which plays a major role in improving growth and yield of crops.

\section{Materials and Methods}

Present investigation was conducted in Department of Agricultural Microbiology University of Agricultural Sciences, GKVK campus, Bangalore, India.
Bioassay of phytohormone production by PGPR and biocontrol agents under in vitro condition

Bioassay for Gibberellic acid, Indole acetic acid (IAA) and Cytokinin were determined by Starch agar halo test, Cucumber root elongation bioassay (Loper and Schroth, 1986) and Cucmber cotyledon greening bioassay (Fletcher et al., 1982).

\section{Preparation of organic liquid formulation}

\section{Preparation of jeevamrutha}

Jeevamrutha was prepared by mixing $10 \mathrm{~kg}$ of desi cow dung, 10 liter of cow urine, $2 \mathrm{~kg}$ of jaggery, $2 \mathrm{~kg}$ horse gram flour and hand full of soil collected from farm. All these were put in 200 litre plastic drum and mixed thoroughly and volume was made up to 200 litres. The mixture was stirred well in clock wise direction and kept the plastic drum in shade covered with wet jute bag. Solution was stirred clockwise in the morning, afternoon and evening for 9 days and it was used for soil application or root dipping of seedlings. Jeevamrutha (500 litre acre ${ }^{-1}$ ) was applied at the time of sowing (Palekar 2005 and Devakumar et al., 2011).

\section{Plant nutrient analysis}

Nitrogen, Phosphorus and Potassium content (\%) in plant on dry weight basis was determined by micro Kjeldhal method as given by Jackson (1973).

Microbial and organic formulations for growth promotions and biocontrol activities in baby corn (Zea mays L.) in pot culture experiments under greenhouse condition

For this purpose, red soil was autoclaved two times at three days interval at 15 psi for 60 minutes in autoclavable polybags. The 
autoclaved soil was amended with according to the treatments of recommended dose of fertilizer (150:75:40 NKP Kg ha ${ }^{-1}$ ) through Nequivalent amount of nitrogen were supplemented through vermicompost and jeevamrutha organic liquid formulations. Vermicompost were applied one week before sowing and jeevamruth organic liquids were applied at the time of sowing into pots. The prepared liquid cultures were applied as per treatments prior to one week of sowing according to treatments given below and seeds were treated with respective liquid cultures.

Three replications were maintained for each treatment and sowing was done. The plants were sprayed at every 15 days intervals after sowing upto harvesting with biocontrol agents viz., Pseudomonas fluorescens and Bacillus subtilis, entomopathogenic fungi and bacteria viz., Beauveria bassiana, Bacillus thuringiensis and Photorhabdus luminescens was sprayed at every 10 days after sowing intervals upto harvesting. The pots were watered alternate days and the growth was observed and biometric parameters were recorded.

\section{Observations recorded}

\section{Germination percentage}

The observation on the germination percentage in different treatments were recorded.

No. of seeds germinated Percentage seed germination $=$---------- $\times 100$

Total number of seeds sown

\section{Plant height (cm)}

The plant height was measured from the soil surface to the tip at the intervals of 20,40, 60 DAS and at harvest. The average height was recorded and expressed in $\mathrm{cm}$.

\section{Number of leaves per plant}

Number of fully opened green leaves was recorded at 20, 40, 60 DAS and at harvest and the average was taken.

\section{Chlorophyll content}

Leaf chlorophyll content was recorded at 20, 40, 60 DAS and at harvest and were determined by method Hervey et al., (2001) using a chlorophyll meter (SPAD-502, Minolta France SA, Currieres-Sur-Seine, France) where light absorbance in red and infrared light was used to measure the chlorophyll content. Chlorophyll meter observations were expressed as SPAD readings.

\section{Days to $50 \%$ Tasseling}

The number of days taken from date of sowing to the stage when 50 per cent of plants have projected tassels out, in each treatment was considered as number of days to 50 per cent tasseling.

\section{Days to $50 \%$ silking}

The number of days taken from date of sowing to the stage when the plants showed extrusion of silks was counted and expressed as days to silking.

\section{Days to harvest}

The number of days taken from date of sowing to the stage of harvesting in each treatment was recorded.

\section{Cob parameters}

\section{Number of cobs per plant}

The number of cobs per plant was taken at the time of harvest and expressed in number of cobs per plant. 


\section{Length of baby corn (cm)}

The length of with husk and without husk of baby corn was measured from the tip to bottom of cob and the mean length was recorded in $\mathrm{cm}$.

\section{Girth of baby corn (cm)}

The width of with husk and without husk of baby corn was measured at the centre of cob and corn the mean of width was worked out in $\mathrm{cm}$.

Weight of baby corn (cob) with husk (g) and without husk per plant (g)

The weight of baby corn (cobs) were recorded with the husk, without husk and the average weight of baby corn per plant was recorded in gm.

Total plant biomass of shoot and root dry weight per plant $(g)$

Five randomly selected plants were harvested. These plants were air dried initially and then oven dried at $60{ }^{\circ} \mathrm{C} \pm 1{ }^{\circ} \mathrm{C}$ till two consecutive weights were constant and shoot and dry weight was recorded as gram per plant.

\section{Results and Discussion}

\section{Plant growth hormone production}

\section{Gibberellic Acid $\left(\mu \mathrm{g} \mathrm{ml}^{-1}\right)$}

The GA concentration of PGPR and biocontrol agents was determined by starch agar halo test is presented in Table 1 and Plate 1. The highest productions of GA concentration was recorded in Pseudomonas fluorescens (3.99 $\mu \mathrm{g} \mathrm{ml} \mathrm{ml}^{-1}$ ) followed by Gluconoacetobacter diazatrophicus $(2.99 \mu \mathrm{g}$ $\left.\mathrm{ml}^{-1}\right)$, Bacillus megaterium $\left(2.66 \mu \mathrm{g} \mathrm{ml}^{-1}\right)$ and Bacillus subtilis $(2.33 \mu \mathrm{g})$. Least productions of GA were obtained from Frateuria aurantia $\left(1.33 \mu \mathrm{g} \mathrm{ml}^{-1}\right)$.

Our results are in conformity with Amanda (2016) who identified that reported and identified Pseudomonas sp $\left(5.43 \mu \mathrm{g} \mathrm{ml} \mathrm{m}^{-1}\right)$ recorded highest GA than Achromobacter xylooxidans $\left(5.25 \mu \mathrm{g} \mathrm{ml}^{-1}\right)$, Bacillus sp $(4.17$ $\mu \mathrm{g} \mathrm{ml}{ }^{-1}$ ).

\section{Indole Acetic Acid (IAA) ( $\left.\mu \mathrm{g} \mathrm{ml}^{-1}\right)$}

The bioassay for IAA was based on the root elongation in cucumber by IAA production. As the IAA concentration increases, the root length of germinating seedlings also increases. The results of the bioassay are presented in Table 1 and Plate 2. The liquid culture of Pseudomonas fluorescens produces highest production of IAA $\left(58.46 \mu \mathrm{g} \mathrm{ml}^{-1}\right)$ which was followed by Gluconoacetobacter diazatrophicus $\left(51.84 \mu \mathrm{g} \mathrm{ml} \mathrm{ml}^{-1}\right)$, Bacillus subtilis (49.26 $\mu \mathrm{g} \mathrm{ml}^{-1}$ ) and Trichoderma harzianum $\left(46.57 \mu \mathrm{g} \mathrm{ml}^{-1}\right)$ recorded least IAA production.

Non-significant difference was observed between Frateuria aurantia $\left(37.13 \mu \mathrm{g} \mathrm{ml}^{-1}\right)$ and Piriformaspora indica $\left(38.58 \mu \mathrm{g} \mathrm{ml}^{-1}\right)$ in regard to IAA production both and were at par with each other.

Karnwal (2009) who have also reported isolated pseudomonad strains from rhizosphere soils and identified that the Pseudomonas fluorescens AK1 and Pseudomonas aeruginosa AK2 showed the best plant growth promoting activity.

These isolates were tested for their ability to produce IAA in pure culture for both strains. Production of indole was increased with the increase in tryptophan concentration. $P$. aeruginosa AK2 was less effective in production of indole acetic acid than $P$. fluorescens AK1. 


\section{Cytokinin $\left(\mu \mathrm{g} \mathrm{ml}^{-1}\right)$}

The cucumber cotyledon greening bioassay was used for detection of cytokinins and the results of the tested cultures are shown in Table 1 and Plate 3. The Pseudomonas fluorescens $\left(3.02 \mu \mathrm{g} \quad \mathrm{ml}^{-1}\right)$ significantly recoded highest cytokinin production followed by Bacillus subtilis (2.05 $\left.\mu \mathrm{g} \quad \mathrm{ml}^{-1}\right)$, Gluconoacetobacter diazatrophicus $(1.83 \mu \mathrm{g}$ $\left.\mathrm{ml}^{-1}\right)$. Frateuria aurantia $\left(1.30 \mu \mathrm{g} \mathrm{ml}^{-1}\right)$ and Piriformaspora indica $\left(1.34 \mu \mathrm{g} \mathrm{ml}^{-1}\right)$ recorded lowest production of cytokinin which were on par with each other. Our results are similarity Amanda, (2016) who reported that Pseudomonas sp $\left(5.42 \mu \mathrm{g} \mathrm{ml} \mathrm{ml}^{-1}\right)$ produced highest cytokinin followed by the Azotobacter chroococcum $\left(3.05 \mu \mathrm{g} \mathrm{ml}^{-1}\right)$.

Effect of microbial and organic formulations on growth parameters of baby corn (Zea mays L.) at different intervals in pot culture under greenhouse condition

\section{Per cent germination}

Effect of microbial and organic formulations on per cent germination were found to be nonsignificant represents in Table 2.

Plant growth parameters of plant height (cm) and number of leaves

In general inoculation of PGPR, biocontrol agent and organic formulations treatments either singly or in combinations increased the plant height at all the intervals presented in Table 2 and Plate 4. The highest plant height was observed in combined inoculation of PGPR, biocontrol agents along with organic formulation and the best among the combination was $\mathrm{T}_{16}(50 \%$ Vermicompost + $50 \%$ Jeevamrutha + Gluconacetobacter diazotrophicus + Bacillus megaterium + Piriformospora indica+ Pseudomonas fluorescens + Bacillus subtilis + Trichoderma harzianum). The increased plant height is attributed to the increased nutrient uptake, particularly nitrogen by the plant due to the activity of microorganisms in rhizosphere soil.

The increased plant height is attributed to increased nutrient uptake, particularly nitrogen by the plant due to the activity of microorganisms in rhizosphere soil.

Similarly, average number of leaves at 20, 40, 60 and at harvest DAS was significantly higher in combined application $\mathrm{T}_{16}(50 \%$ Vermicompost $+50 \%$ Jeevamrutha+ Gluconacetobacter diazotrophicus + Bacillus megaterium + Piriformospora indica+ Pseudomonas fluorescens + Bacillus subtilis + Trichoderma harzianum) over control. Among all treatments the single inoculations recorded at all the intervals $(20,40,60$ DAS and at harvest) increased linearly and maximum was found in the $\mathrm{T}_{16}(50 \%$ Vermicompost $+50 \%$ Jeevamrutha + Gluconacetobacter diazotrophicus + Bacillus megaterium + Piriformospora indica+ Pseudomonas fluorescens + Bacillus subtilis + Trichoderma harzianum). The combined inoculation of PGPR, biocontrol agents and organic formulations further increased the number of leaves per plant. However, the combined inoculation of PGPR, biocontrol agents and organic formulations was found best among all the treatment.

The increased number of leaves might be due to the response of nitrogen and is a major plant nutrient that triggers the vegetative growth of plants. These results were in accordance with Rudresh et al., (2004) who carried out experiments using PGPR and biocontol agents and observed that increased growth of chickpea with combined inoculation of biocontrol agent (Trichoderma sp.) and beneficial organisms like P-solubilizer and nitrogen fixer (Bacillus megaterium and Rhizobium sp.) 
Effect of microbial and organic formulations on chlorophyll content and days taken to $\mathbf{5 0}$ per cent tasseling, silking and harvesting baby corn (Zea mays $\mathrm{L}_{\text {.) }}$ at different intervals in pot culture under green house condition

The chlorophyll content and days to 50 per cent tasseling, silking and harvesting of baby corn enhanced with the application of microbial and organic formulations in different combination and the data is interpreted in Table 3.

The application of microbial and organic formulations in individual and different combinations on baby corn under greenhouse condition have shown positive influence on chlorophyll content at all the intervals viz., 20, 40, 60 and at harvest. Treatment $\mathrm{T}_{16}$ received microbial and organic formulations recorded maximum chlorophyll content at all the intervals 20, 40, 60 and at harvest (26.37, $32.70,34.68$ and 35.67$)$ followed by $\mathrm{T}_{14}(50 \%$ Vermicompost $+50 \%$ Jeevamrutha + Vermicompost + Jeevamrutha+ Gluconacetobacter diazotrophicus + Bacillus megaterium + Piriformospora indica) at 20 DAS (24.67) and 40 DAS (28.10) and at 60 DAS and harvest $\mathrm{T}_{8}$ (32.48), $\mathrm{T}_{11}$ (33.47) which were on par with each other.

It was previously reported by Vadiraj et al., 1998 that the nitrogen being the major constituent of chlorophyll therefore increases in nitrogen availability leads to increase in chlorophyll content. The significantly organic treatments may be attributed to the higher levels of nutrients besides growth stimulating substances (enzymes, antibiotics and growth hormones) available in vermicompost.

Significant increase in chlorophyll content was recorded due to increased absorption of nutrients which resulted in increase in the synthesis of carbohydrates, and increased activity of hormones produced by Azospirillum and phosphate solubilizing bacteria (PSB).

The PSB root treatment might have increased phosphate availability in the soils which in turn helped better proliferation of root growth and uptake of other nutrients to a greater extent. The enlargement in cell size and cell division might have helped in increasing plant height and number of leaves per plant. These results are in agreement in brinjal with those of Nanthakumar and Veeraraghavathatham (2000) and Wange and Kale (2004).

Days taken for 50 per cent taselling, silking and harvesting

Application of microbial and organic formulations showed significant difference with respect to the number of days to 50 per cent tasseling.

Plate.1 Gibberellic Acid production by PGPR and biocontrol agent biocontrol agents
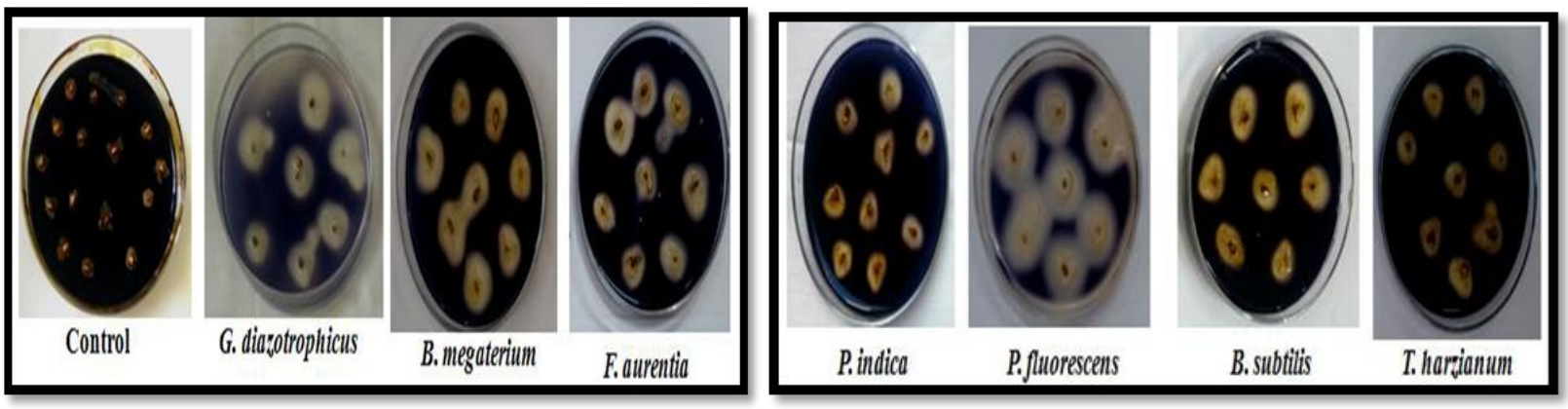
Plate.2 IAA production by PGPR and biocontrol agent

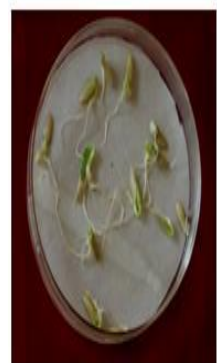

Control

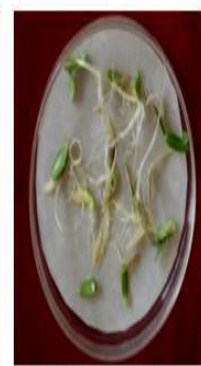

G. diavotrophicus

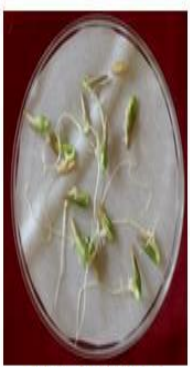

B. meguterium

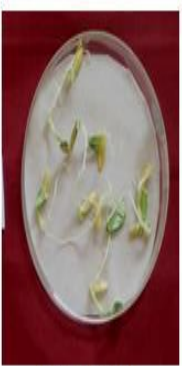

F. aurentia

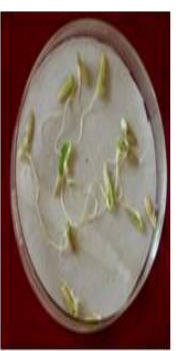

P.indica

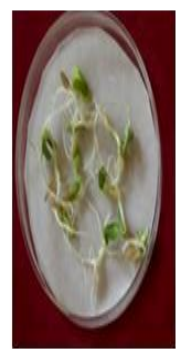

P.fluorescens

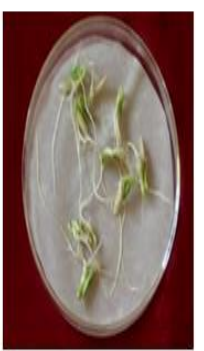

B. subtilis

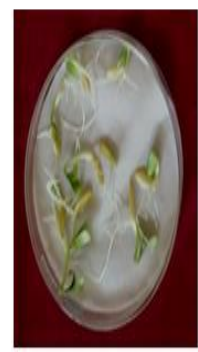

T. harrianum

Plate.3 Cytokinin production by PGPR and biocontrol agents

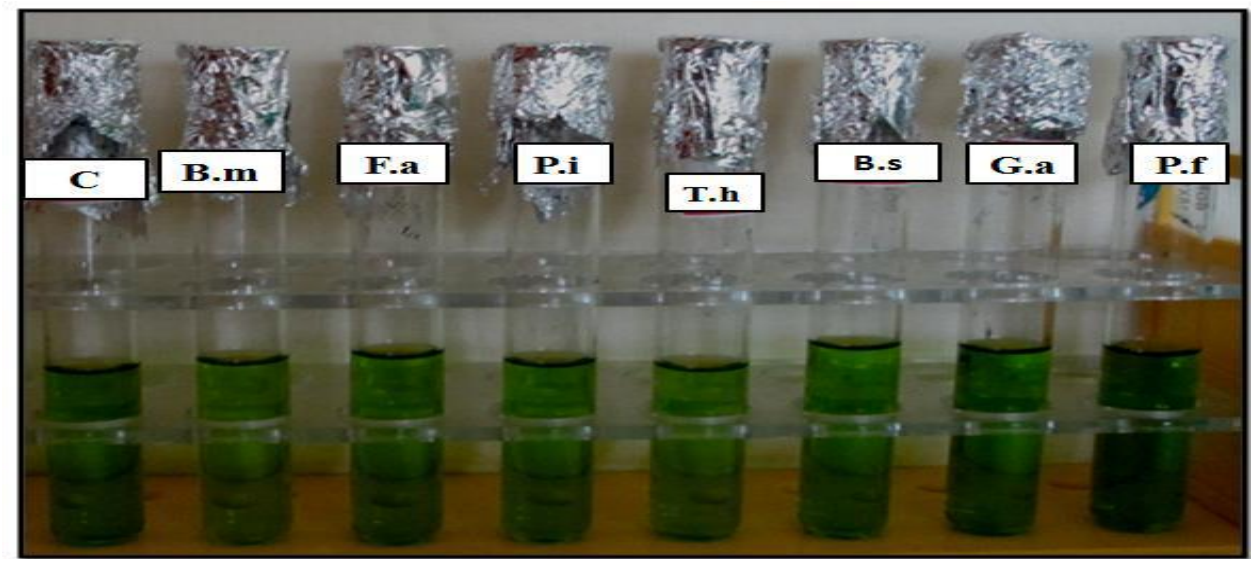

Plate.4 General view of pot experiment on baby corn (Zea mays L.) at harvesting time under greenhouse condition

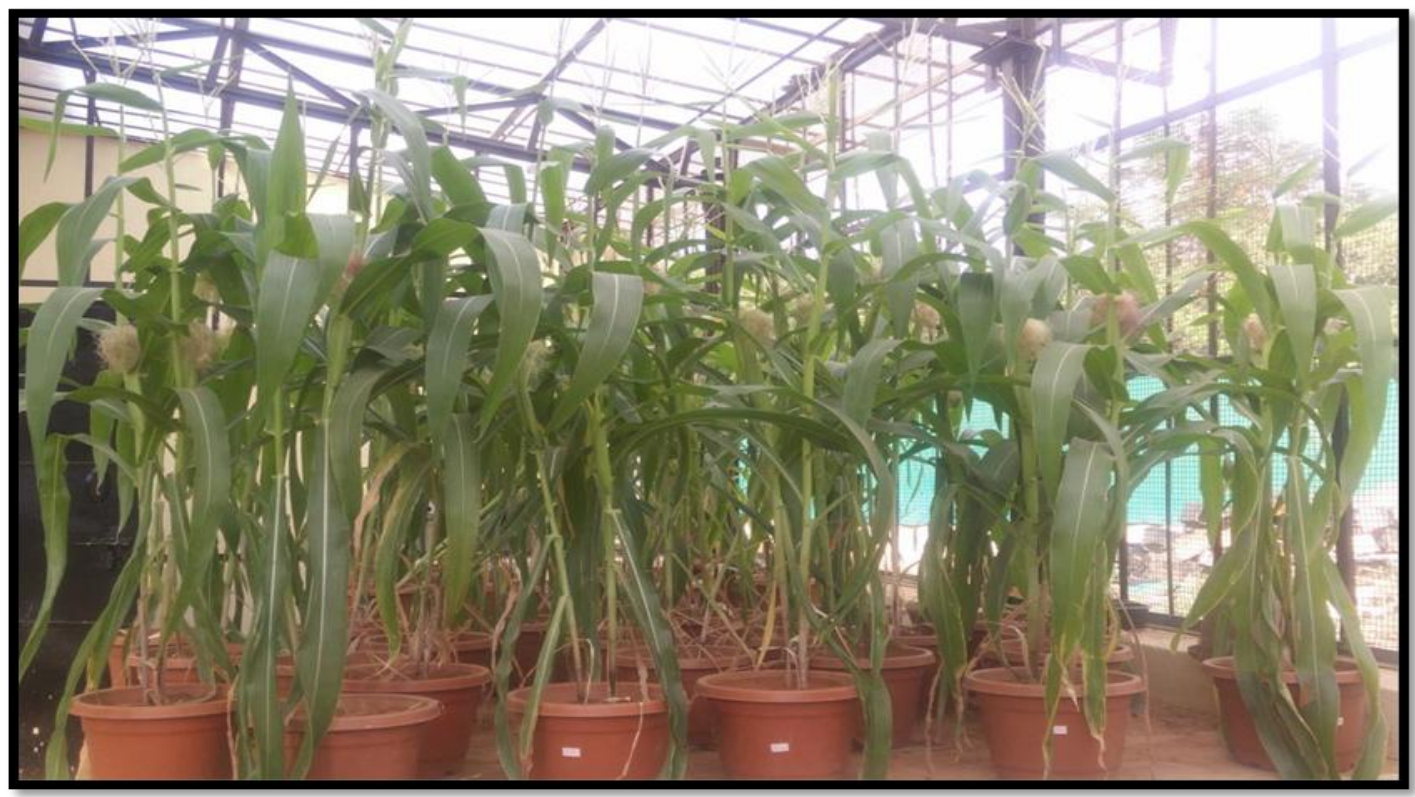




\begin{tabular}{|c|c|c|c|}
\hline Crop: Baby corn & $\begin{array}{c}\text { Scientific name: Zea mays } \\
\text { L. }\end{array}$ & $\begin{array}{c}\text { Variety: G } \\
5414\end{array}$ & $\begin{array}{c}\text { Vermicompost: } 10 \\
\text { ton ha }^{-1}\end{array}$ \\
\hline $\begin{array}{c}\text { Jeevamrutha: } 400-500 \\
\text { liter acre }\end{array}$ & Treatments: 16 & Replication: 3 & Design: CRD \\
\hline
\end{tabular}

\section{Treatment details}

\begin{tabular}{|c|c|}
\hline $\mathrm{T}_{1}$ & Control \\
\hline $\mathbf{T}_{2}$ & $100 \%$ Vermicompost $(\mathrm{V})$ \\
\hline $\mathbf{T}_{3}$ & $100 \%$ Jeevamrutha $(\mathrm{J})$ \\
\hline$\overline{T_{4}}$ & $50 \%$ Vermicompost $(\mathrm{V})+50 \%$ Jeevamrutha $(\mathrm{J})$ \\
\hline $\mathbf{T}_{5}$ & $50 \%$ Vermicompost $(\mathrm{V})+50 \% \mathrm{RDF}$ \\
\hline $\mathrm{T}_{6}$ & $50 \%$ Jeevamrutha $(\mathrm{J})+50 \%$ RDF \\
\hline $\mathbf{T}_{7}$ & $25 \%$ Vermicompost $(\mathrm{V})+25 \%$ Jeevamrutha $(\mathrm{J})+50 \% \mathrm{RDF}$ \\
\hline $\mathrm{T}_{8}$ & Gluconacetobacter diazotrophicus (G.a) \\
\hline$T_{9}$ & Bacillus megaterium (B.m) \\
\hline $\mathrm{T}_{10}$ & Piriformospora indica (P.i) \\
\hline $\mathbf{T}_{11}$ & Pseudomonas fluorescens (P.f) \\
\hline$T_{12}$ & Bacillus subtilis (B.s) \\
\hline $\mathbf{T}_{13}$ & Trichoderma harzianum (T.h) \\
\hline $\mathrm{T}_{14}$ & $\begin{array}{l}\text { Gluconacetobacter diazotrophicus (G.a) +Bacillus megaterium (B.m) +Piriformospora } \\
\text { indica (P.i) }\end{array}$ \\
\hline $\mathbf{T}_{15}$ & Pseudomonas fluorescens (P.f) + Bacillussubtilis (B.s) + Trichoderma harzianum (T.h) \\
\hline $\mathbf{T}_{16}$ & $\begin{array}{l}\text { Gluconacetobacter diazotrophicus (G.a) +Bacillus megaterium (B.m) + Piriformospora } \\
\text { indica (P.i) + Pseudomonas fluorescens (P.f) }+ \text { Bacillus subtilis (B.s) +Trichoderma } \\
\text { harzianum (T.h) }\end{array}$ \\
\hline
\end{tabular}

Note: 50 per cent of vermicompost and 50 per cent jeevamrutha was common for $T_{8}$ to $T_{16}$ as per package of practices given UAS, Bengaluru.

Table.1 Plant growth hormone production by PGPR and biocontrol agents

\begin{tabular}{|l|c|c|c|}
\hline \multicolumn{1}{|c|}{ PGPR and biocontrol agents } & $\begin{array}{c}\text { Gibberellic acid } \\
\left.(\mu \mathrm{g} \mathrm{ml})^{-1}\right)\end{array}$ & $\begin{array}{c}\text { Indole Acetic } \\
\text { Acid }\left(\mu \mathrm{ng} \mathrm{ml}^{-1}\right)\end{array}$ & $\begin{array}{c}\text { Cytokinine } \\
\left(\mu \mathrm{g} \mathrm{ml}^{-1}\right)\end{array}$ \\
\hline Gluconacetobacter diazotrophicus & $2.99^{\mathrm{b}}$ & $51.84^{\mathrm{b}}$ & $1.83^{\mathrm{c}}$ \\
\hline Bacillus megaterium & $2.66^{\mathrm{c}}$ & $44.04^{\mathrm{e}}$ & $1.45^{\mathrm{d}}$ \\
\hline Frateuria aurantia & $1.33^{\mathrm{g}}$ & $37.13^{\mathrm{f}}$ & $1.30^{\mathrm{e}}$ \\
\hline Piriformaspora indica & $1.69^{\mathrm{f}}$ & $38.58^{\mathrm{f}}$ & $1.34^{\mathrm{e}}$ \\
\hline Pseudomonas fluorescens & $3.99^{\mathrm{a}}$ & $58.46^{\mathrm{a}}$ & $3.02^{\mathrm{a}}$ \\
\hline Bacillus subtilis & $2.33^{\mathrm{d}}$ & $49.26^{\mathrm{c}}$ & $2.05^{\mathrm{b}}$ \\
\hline Trichoderma harzianum & $2.06^{\mathrm{e}}$ & $46.57^{\mathrm{d}}$ & $1.42^{\mathrm{d}}$ \\
\hline
\end{tabular}

Note: Means with the same superscript donot differ significantly @ $\mathrm{P}=<0.05$ as per DMRT. 
Table.2 Effect of microbial and organic formulations on growth parameters of baby corn (Zea mays L.) at different intervals in pot culture under greenhouse condition

\begin{tabular}{|c|c|c|c|c|c|c|c|c|c|}
\hline \multirow[t]{2}{*}{ Treatments } & \multirow{2}{*}{$\begin{array}{c}\text { Per cent } \\
\text { germination }\end{array}$} & \multicolumn{4}{|c|}{ Plant height (cm) } & \multicolumn{4}{|c|}{ Number of leaves } \\
\hline & & $\begin{array}{c}20 \\
\text { DAS }\end{array}$ & $\begin{array}{c}40 \\
\text { DAS }\end{array}$ & $\begin{array}{c}\text { 60 } \\
\text { DAS }\end{array}$ & $\begin{array}{c}\text { At } \\
\text { harvest }\end{array}$ & $\begin{array}{c}20 \\
\text { DAS }\end{array}$ & $\begin{array}{c}40 \\
\text { DAS }\end{array}$ & $\begin{array}{c}\text { 60 } \\
\text { DAS }\end{array}$ & $\begin{array}{c}\text { At } \\
\text { harvest }\end{array}$ \\
\hline $\mathbf{T}_{1}$ & 93.33 & $15.07^{\mathrm{g}}$ & $40.28^{\mathrm{h}}$ & $81.51^{\mathrm{i}}$ & $110.50^{\mathrm{k}}$ & $5.00^{\mathrm{e}}$ & $6.65^{\mathrm{g}}$ & $8.65^{\mathrm{i}}$ & $11.33^{\mathrm{f}}$ \\
\hline $\mathrm{T}_{2}$ & 96.83 & $20.57^{\mathrm{f}}$ & $54.12^{\mathrm{g}}$ & $95.35^{\mathrm{h}}$ & $124.34^{\mathrm{ij}}$ & $5.33^{\mathrm{d}}$ & $7.33^{\mathrm{e}}$ & $9.33^{\mathrm{gh}}$ & $12.66^{\mathrm{de}}$ \\
\hline $\mathrm{T}_{3}$ & 96.13 & $21.07^{\mathrm{ef}}$ & $58.78^{\mathrm{f}}$ & $93.80^{\mathrm{h}}$ & $123.79^{j}$ & $5.00^{\mathrm{e}}$ & $7.00^{f}$ & $9.33^{\mathrm{gh}}$ & $12.66^{\mathrm{de}}$ \\
\hline $\mathbf{T}_{4}$ & 96.33 & $21.67^{\mathrm{de}}$ & $60.38^{\text {def }}$ & $96.10^{\mathrm{h}}$ & $125.09^{\text {hij }}$ & $5.33^{\mathrm{d}}$ & $7.66^{d}$ & $9.66^{\mathrm{fg}}$ & $12.99^{\mathrm{cd}}$ \\
\hline$T_{5}$ & 96.88 & $20.63^{\mathrm{f}}$ & $62.00^{\mathrm{d}}$ & $103.23^{\text {efg }}$ & $128.22^{\text {efghi }}$ & $6.00^{\mathrm{c}}$ & $7.00^{f}$ & $9.33^{\mathrm{gh}}$ & $12.66^{\mathrm{de}}$ \\
\hline$T_{6}$ & 96.33 & $20.67^{f}$ & $60.38^{\text {def }}$ & $101.61^{\mathrm{g}}$ & $130.60^{\mathrm{ef}}$ & $6.00^{c}$ & $7.00^{f}$ & $9.00^{\mathrm{h}}$ & $12.33^{\mathrm{e}}$ \\
\hline $\mathbf{T}_{7}$ & 98.13 & $22.12^{\mathrm{d}}$ & $64.73^{c}$ & $110.96^{\mathrm{bc}}$ & $139.95^{\mathrm{c}}$ & $6.00^{c}$ & $7.77^{\text {cd }}$ & $9.77^{\mathrm{f}}$ & $13.33^{\mathrm{bc}}$ \\
\hline $\mathrm{T}_{8}$ & 97.33 & $21.87^{\mathrm{d}}$ & $59.58^{\mathrm{ef}}$ & $110.10^{\mathrm{bc}}$ & $129.09^{\mathrm{efgh}}$ & $6.00^{c}$ & $8.00^{c}$ & $10.66^{\mathrm{cd}}$ & $13.99^{\mathrm{ab}}$ \\
\hline $\mathrm{T}_{9}$ & 96.63 & $21.72 \mathrm{~d}^{\mathrm{e}}$ & $55.43^{\mathrm{g}}$ & $108.66^{\mathrm{cd}}$ & $127.65^{\text {fghij }}$ & $5.00^{\mathrm{e}}$ & $8.00^{c}$ & $10.33^{\mathrm{de}}$ & $13.66^{\mathrm{ab}}$ \\
\hline$T_{10}$ & 96.33 & $21.87^{\mathrm{d}}$ & $54.58^{\mathrm{g}}$ & $103.81^{\mathrm{efg}}$ & $125.80^{\text {ghij }}$ & $5.00^{\mathrm{e}}$ & $8.00^{c}$ & $10.00^{\mathrm{ef}}$ & $13.33^{\mathrm{bc}}$ \\
\hline$T_{11}$ & 98.68 & $24.45^{\mathrm{b}}$ & $64.16^{\mathrm{c}}$ & $105.39^{\mathrm{def}}$ & $132.38^{\mathrm{de}}$ & $6.33^{b}$ & $8.66^{\mathrm{a}}$ & $11.66^{\mathrm{a}}$ & $13.66^{\mathrm{ab}}$ \\
\hline$T_{12}$ & 97.58 & $23.23^{c}$ & $60.94^{\text {de }}$ & $102.17^{\mathrm{fg}}$ & $130.16^{\mathrm{efg}}$ & $6.00^{c}$ & $8.00^{c}$ & $10.33^{\text {de }}$ & $13.66^{\mathrm{ab}}$ \\
\hline$T_{13}$ & 97.83 & $23.56^{\mathrm{c}}$ & $65.27^{c}$ & $106.50^{\mathrm{de}}$ & $135.49^{\mathrm{d}}$ & $6.00^{c}$ & $8.00^{c}$ & $11.00^{\mathrm{bc}}$ & $13.33^{b c}$ \\
\hline$T_{14}$ & 98.33 & $25.03^{b}$ & $75.24^{b}$ & $121.47^{\mathrm{a}}$ & $147.55^{\mathrm{b}}$ & $6.00^{c}$ & $8.33^{b}$ & $11.33^{\mathrm{ab}}$ & $13.33^{\mathrm{bc}}$ \\
\hline$T_{15}$ & 98.21 & $23.12^{c}$ & $73.33^{b}$ & $112.56^{\mathrm{b}}$ & $144.46^{\mathrm{b}}$ & $6.00^{c}$ & $8.00^{c}$ & $11.00^{b c}$ & $13.66^{\mathrm{ab}}$ \\
\hline$T_{16}$ & 98.68 & $26.25^{\mathrm{a}}$ & $81.96^{\mathrm{a}}$ & $123.19^{\mathrm{a}}$ & $152.18^{\mathrm{a}}$ & $6.66^{\mathrm{a}}$ & $8.66^{\mathrm{a}}$ & $11.66^{\mathrm{a}}$ & $13.99^{\mathrm{a}}$ \\
\hline
\end{tabular}

Note: Means with the same superscript donot differ significantly @ $\mathrm{P}=<0.05$ as per DMRT.

Table.3 Effect of microbial and organic formulations on chlorophyll content and days taken for harvesting of baby corn (Zea mays L.) at different intervals in pot culture under greenhouse condition

\begin{tabular}{|c|c|c|c|c|c|c|c|}
\hline \multirow[t]{2}{*}{ Treatments } & \multicolumn{4}{|c|}{ Chlorophyll content } & \multicolumn{3}{|c|}{ Number of days } \\
\hline & $\begin{array}{c}20 \\
\text { DAS }\end{array}$ & $\begin{array}{c}40 \\
\text { DAS }\end{array}$ & $\begin{array}{c}60 \\
\text { DAS }\end{array}$ & $\begin{array}{c}\text { At } \\
\text { Harvest }\end{array}$ & $\begin{array}{l}\text { Days Taken for } \\
50 \% \text { Tasseling }\end{array}$ & $\begin{array}{c}\text { Days taken for } \\
\mathbf{5 0} \% \text { Silking }\end{array}$ & $\begin{array}{c}\text { Days to } \\
\text { harvesting }\end{array}$ \\
\hline$T_{1}$ & $15.37^{\mathrm{j}}$ & $18.70^{1}$ & $22.68^{j}$ & $23.50^{\mathrm{k}}$ & $74.10^{\mathrm{a}}$ & $78.60^{\mathrm{a}}$ & $82.10^{\mathrm{a}}$ \\
\hline$T_{2}$ & $21.80^{\mathrm{g}}$ & $24.13^{\mathrm{h}}$ & $26.11^{\mathrm{i}}$ & $27.10^{j}$ & $70.00^{\mathrm{bcd}}$ & $74.00^{\text {cde }}$ & $77.00^{\text {cde }}$ \\
\hline$\overline{T_{3}}$ & $19.34^{\mathrm{i}}$ & $22.67^{\mathrm{jk}}$ & $27.65^{\mathrm{h}}$ & $28.64^{i}$ & $71.00^{\mathrm{bc}}$ & $75.30^{\text {bcd }}$ & $78.60^{\mathrm{bc}}$ \\
\hline $\mathbf{T}_{4}$ & $23.77^{\text {cd }}$ & $25.10^{\mathrm{g}}$ & $30.08^{\text {ef }}$ & $31.07^{\mathrm{fg}}$ & $70.50^{\mathrm{bc}}$ & $74.50^{\text {bcd }}$ & $77.50^{\text {cde }}$ \\
\hline$\overline{T_{5}}$ & $20.92^{\mathrm{h}}$ & $24.25^{\mathrm{h}}$ & $29.23^{\mathrm{fg}}$ & $30.22^{\mathrm{gh}}$ & $70.00^{\text {bcd }}$ & $74.00^{\text {cde }}$ & $77.00^{\text {cde }}$ \\
\hline$T_{6}$ & $20.43^{\mathrm{h}}$ & $23.76^{\mathrm{hi}}$ & $28.74^{\mathrm{g}}$ & $29.73^{\mathrm{h}}$ & $72.20^{a b}$ & $76.70^{\mathrm{ab}}$ & $80.20^{\mathrm{ab}}$ \\
\hline $\mathbf{T}_{7}$ & $22.66^{\mathrm{ef}}$ & $25.99^{\mathrm{ef}}$ & $30.97^{\mathrm{de}}$ & $31.96^{\operatorname{def}}$ & $70.00^{\text {bcd }}$ & $74.00^{\text {cde }}$ & $77.00^{\text {cde }}$ \\
\hline $\mathrm{T}_{8}$ & $23.17^{\mathrm{de}}$ & $26.50^{\text {de }}$ & $32.48^{\mathrm{b}}$ & $33.47^{\mathrm{b}}$ & $69.50^{\text {cd }}$ & $73.50^{\text {cde }}$ & $76.50^{\text {cde }}$ \\
\hline$T_{9}$ & $22.88^{\mathrm{e}}$ & $23.21^{\mathrm{ij}}$ & $31.19^{\mathrm{cd}}$ & $32.18^{\text {cde }}$ & $71.00^{\mathrm{bc}}$ & $75.40^{\mathrm{bcd}}$ & $78.80^{\mathrm{bc}}$ \\
\hline$T_{10}$ & $20.79^{\mathrm{h}}$ & $22.12^{\mathrm{k}}$ & $30.10^{\text {ef }}$ & $31.09^{\mathrm{fg}}$ & $71.20^{\mathrm{bc}}$ & $75.50^{\mathrm{bc}}$ & $78.80^{\mathrm{bc}}$ \\
\hline $\mathrm{T}_{11}$ & $24.22^{\mathrm{bc}}$ & $27.55^{\mathrm{bc}}$ & $32.53^{\mathrm{b}}$ & $33.52^{\mathrm{b}}$ & $69.00^{\mathrm{cd}}$ & $73.00^{\mathrm{de}}$ & $76.00^{\mathrm{de}}$ \\
\hline$T_{12}$ & $23.79^{\text {cd }}$ & $25.12^{\mathrm{g}}$ & $29.10^{\mathrm{fg}}$ & $30.09^{\mathrm{gh}}$ & $70.30^{\mathrm{bcd}}$ & $74.60^{\mathrm{bcd}}$ & $77.90^{\mathrm{bcd}}$ \\
\hline$T_{13}$ & $22.12^{\mathrm{fg}}$ & $25.45^{\mathrm{fg}}$ & $30.43^{\mathrm{de}}$ & $31.42^{\mathrm{ef}}$ & $70.50^{\mathrm{bc}}$ & $74.50^{\mathrm{bcd}}$ & $77.50^{\text {cde }}$ \\
\hline $\mathrm{T}_{14}$ & $24.67^{b}$ & $28.10^{b}$ & $32.08^{\mathrm{bc}}$ & $33.07^{\mathrm{bc}}$ & $69.00^{\text {cd }}$ & $73.00^{\mathrm{de}}$ & $76.00^{\mathrm{de}}$ \\
\hline$T_{15}$ & $23.77^{\mathrm{cd}}$ & $27.05^{\mathrm{cd}}$ & $31.98^{\mathrm{bc}}$ & $32.97^{\mathrm{bcd}}$ & $69.50^{\text {cd }}$ & $73.50^{\text {cde }}$ & $76.50^{\text {cde }}$ \\
\hline$T_{16}$ & $26.37^{\mathrm{a}}$ & $32.70^{\mathrm{a}}$ & $34.68^{\mathrm{a}}$ & $35.67^{a}$ & $68.00^{\mathrm{d}}$ & $72.00^{\mathrm{e}}$ & $75.00^{\mathrm{e}}$ \\
\hline
\end{tabular}

Note: Means with the same superscript donot differ significantly @ $\mathrm{P}=<0.05$ as per DMRT. 
Table.4 Effect of microbial and organic formulations on cob parameters, plant biomass and nutient content of baby corn (Zea mays L.) in pot culture under greenhouse condition

\begin{tabular}{|c|c|c|c|c|c|c|c|c|c|c|c|}
\hline \multirow[t]{2}{*}{ Treatments } & \multirow[t]{2}{*}{$\begin{array}{l}\text { Number of } \\
\text { cobs plant }^{-1}\end{array}$} & \multicolumn{2}{|c|}{ Cob length (cm) } & \multicolumn{2}{|c|}{ Cob girth (cm) } & \multicolumn{2}{|c|}{$\begin{array}{l}\text { Weight of cobs } \\
\quad\left(g \text { plant }^{-1}\right)\end{array}$} & \multirow{2}{*}{$\begin{array}{c}\text { Plant } \\
\text { biomass }^{\left(g_{\text {plant }}^{-1}\right)}\end{array}$} & \multicolumn{3}{|c|}{ Nutrient (\%) } \\
\hline & & $\begin{array}{l}\text { With } \\
\text { husk }\end{array}$ & $\begin{array}{c}\text { Without } \\
\text { husk }\end{array}$ & $\begin{array}{l}\text { With } \\
\text { husk }\end{array}$ & $\begin{array}{l}\text { Without } \\
\text { husk }\end{array}$ & $\begin{array}{l}\text { With } \\
\text { husk }\end{array}$ & $\begin{array}{c}\text { Without } \\
\text { husk }\end{array}$ & & $\begin{array}{l}\text { Nitrogen } \\
(\%)\end{array}$ & $\begin{array}{c}\text { Phosphorus } \\
(\%)\end{array}$ & $\begin{array}{c}\text { Potassium } \\
(\%)\end{array}$ \\
\hline$\overline{T_{1}}$ & $2.00^{\mathrm{f}}$ & $14.00^{\mathrm{j}}$ & $5.30^{\mathrm{j}}$ & $4.10^{\mathrm{i}}$ & $2.30^{\mathrm{k}}$ & $45.88^{\mathrm{j}}$ & $15.88^{1}$ & $101.90^{\mathrm{i}}$ & $1.01^{\mathrm{k}}$ & $0.15^{\mathrm{m}}$ & $0.70^{\mathrm{h}}$ \\
\hline$T_{2}$ & $2.13^{\mathrm{e}}$ & $16.21^{\mathrm{i}}$ & $7.10^{i}$ & $5.25^{\mathrm{h}}$ & $3.14^{\mathrm{j}}$ & $55.90^{\mathrm{i}}$ & $21.91^{\mathrm{j}}$ & $116.56^{\mathrm{gh}}$ & $1.47^{i}$ & $0.34^{\mathrm{k}}$ & $0.92^{\mathrm{g}}$ \\
\hline$\overline{T_{3}}$ & $2.00^{f}$ & $16.50^{\mathrm{i}}$ & $7.39^{\mathrm{i}}$ & $5.33^{\mathrm{h}}$ & $3.12^{\mathrm{j}}$ & $55.33^{\mathrm{i}}$ & $20.33^{\mathrm{k}}$ & $112.61^{\mathrm{h}}$ & $1.36^{\mathrm{j}}$ & $0.32^{1}$ & $0.90^{\mathrm{g}}$ \\
\hline$\overline{T_{4}}$ & $2.30^{\mathrm{d}}$ & $17.22^{\mathrm{h}}$ & $8.11^{\mathrm{h}}$ & $5.55^{\mathrm{g}}$ & $3.44^{\mathrm{i}}$ & $61.68^{\mathrm{gh}}$ & $23.68^{i}$ & $126.21^{\mathrm{de}}$ & $1.64^{\mathrm{h}}$ & $0.36^{\mathrm{j}}$ & $0.93^{\mathrm{g}}$ \\
\hline$\overline{T_{5}}$ & $2.34^{\mathrm{d}}$ & $18.11^{\mathrm{f}}$ & $8.55^{\mathrm{g}}$ & $5.21^{\mathrm{h}}$ & $3.11^{\mathrm{j}}$ & $62.88^{\mathrm{g}}$ & $24.88^{\mathrm{gh}}$ & $123.36^{\text {ef }}$ & $1.73^{\mathrm{g}}$ & $0.40^{\mathrm{h}}$ & $0.98^{\mathrm{f}}$ \\
\hline$\overline{T_{6}}$ & $2.00^{\mathrm{f}}$ & $17.76^{\mathrm{tgh}}$ & $9.65^{d}$ & $5.19^{\mathrm{h}}$ & $3.08^{\mathrm{j}}$ & $60.18^{h}$ & $22.18^{j}$ & $120.90^{\mathrm{fg}}$ & $1.83^{\mathrm{f}}$ & $0.38^{\mathrm{i}}$ & $0.92^{\mathrm{g}}$ \\
\hline$\overline{T_{7}}$ & $2.35^{\mathrm{d}}$ & $19.83^{\mathrm{cd}}$ & $9.98^{\mathrm{c}}$ & $5.77^{f}$ & $4.12^{\mathrm{h}}$ & $63.44^{\mathrm{g}}$ & $25.44^{\mathrm{g}}$ & $129.74^{\mathrm{d}}$ & $2.21^{\mathrm{d}}$ & $0.45^{\mathrm{g}}$ & $1.12^{\mathrm{bc}}$ \\
\hline$\overline{T_{8}}$ & $2.49^{c}$ & $18.81^{\mathrm{e}}$ & $9.70^{\mathrm{cd}}$ & $6.55^{\mathrm{cd}}$ & $4.44^{\mathrm{g}}$ & $66.00^{\mathrm{f}}$ & $28.00^{\mathrm{f}}$ & $127.57^{\mathrm{de}}$ & $2.19^{d}$ & $0.48^{\mathrm{f}}$ & $1.01^{\text {ef }}$ \\
\hline$\overline{T_{9}}$ & $2.00^{\mathrm{f}}$ & $17.99^{\mathrm{fg}}$ & $8.88^{\mathrm{f}}$ & $6.75^{\mathrm{c}}$ & $4.64^{\mathrm{t}}$ & $62.95^{\mathrm{g}}$ & $24.15^{\mathrm{hi}}$ & $124.36^{\text {ef }}$ & $1.93^{\mathrm{e}}$ & $0.50^{\mathrm{e}}$ & $0.98^{\mathrm{f}}$ \\
\hline$\overline{T_{10}}$ & $2.00^{\mathrm{f}}$ & $17.15^{\mathrm{h}}$ & $8.04^{\mathrm{h}}$ & $6.19^{\mathrm{e}}$ & $4.08^{h}$ & $62.73^{g}$ & $24.00^{\mathrm{hi}}$ & $121.56^{\mathrm{f}}$ & $1.96^{\mathrm{e}}$ & $0.51^{\mathrm{e}}$ & $1.02^{\mathrm{e}}$ \\
\hline$\overline{T_{11}}$ & $2.60^{\mathrm{b}}$ & $19.50^{\mathrm{d}}$ & $9.30^{\mathrm{e}}$ & $6.43^{d}$ & $4.82^{\mathrm{e}}$ & $69.22^{\mathrm{de}}$ & $30.22^{\mathrm{de}}$ & $137.63^{c}$ & $2.24^{\mathrm{cd}}$ & $0.53^{d}$ & $1.08^{\mathrm{d}}$ \\
\hline$\overline{T_{12}}$ & $2.00^{\mathrm{f}}$ & $17.46^{\mathrm{gh}}$ & $9.28^{\mathrm{e}}$ & $6.10^{\mathrm{e}}$ & $4.12^{\mathrm{h}}$ & $67.58^{\mathrm{ef}}$ & $29.58^{\mathrm{e}}$ & $127.06^{\mathrm{de}}$ & $1.92^{\mathrm{e}}$ & $0.46^{\mathrm{g}}$ & $1.01^{\mathrm{ef}}$ \\
\hline$\overline{T_{13}}$ & $2.50^{c}$ & $19.99^{\mathrm{cd}}$ & $10.00^{c}$ & $6.10^{\mathrm{e}}$ & $4.99^{d}$ & $70.53^{d}$ & $30.53^{d}$ & $137.90^{c}$ & $2.30^{c}$ & $0.50^{\mathrm{e}}$ & $1.10^{\mathrm{cd}}$ \\
\hline$\overline{T_{14}}$ & $2.74^{\mathrm{a}}$ & $20.61^{b}$ & $11.33^{\mathrm{a}}$ & $7.57^{b}$ & $5.45^{\mathrm{b}}$ & $76.67^{b}$ & $34.30^{b}$ & $157.67^{\mathrm{a}}$ & $2.41^{b}$ & $0.66^{\mathrm{b}}$ & $1.15^{\mathrm{ab}}$ \\
\hline $\mathbf{T}_{15}$ & $2.70^{\mathrm{a}}$ & $20.13^{b c}$ & $11.02^{b}$ & $7.75^{b}$ & $5.20^{\mathrm{c}}$ & $73.90^{c}$ & $31.51^{c}$ & $150.57^{b}$ & $2.38^{\mathrm{c}}$ & $0.62^{c}$ & $1.13^{\mathrm{bc}}$ \\
\hline $\mathbf{T}_{16}$ & $2.74^{\mathrm{a}}$ & $22.45^{\mathrm{a}}$ & $11.43^{\mathrm{a}}$ & $8.50^{\mathrm{a}}$ & $5.89^{\mathrm{a}}$ & $79.33^{\mathrm{a}}$ & $36.33^{\mathrm{a}}$ & $161.76^{\mathrm{a}}$ & $2.60^{\mathrm{a}}$ & $0.68^{\mathrm{a}}$ & $1.17^{\mathrm{a}}$ \\
\hline
\end{tabular}

Note: Means with the same superscript donot differ significantly @ $\mathrm{P}=<0.05$ as per DMRT. 
The multiple combined application of PGPR, biocontrol agents along with organic formulations took significantly less number of days to reach 50 percent tasseling (68 days), silking (72 days) and harvesting (75 days) than those which received triplicate and individual application of microbial inoculants and organic formulations with respect to 50 percent tasseling, silking and harvesting.

The delayed tasseling, silking and harvesting in plots receiving more number of days which might be due to low availability of nitrogen to plants. Flowering, fruiting and seed set are essential in crop plant production. These processes are controlled by environment, particularly photoperiod and temperature, and by genetic or internal factors, particularly growth regulators, photosynthate and mineral nutrient supply example nitrogen was reported by Gardner et al., 1988.

Our present results were in accordance with Mai (2004) who reported that earliness of male and female flower might be due to the production of growth substances like GA, IAA from the PGPR which had positive influences on the physiological activity of plants.

Effect of microbial and organic formulations on cob parameters, plant biomass and nutrient content of baby corn (Zea mays L.) in pot culture under greenhouse condition

Data pertaining to individual cob parameters, plant biomass and nutient content of baby corn was furnished in Table 4. It clearly established that the influence of application of combined inoculation of beneficial microorganisms and organic liquid formulations on number of cobs per plant, cob length (with husk and without husk), cob girth (with husk and without husk), and weight of cobs (with husk and without husk), plant biomass and nutrient content. All the inoculated treatments influenced cob parameters when compared to control treatments.

Among all the treatments, multiple inoculated treatment, $\mathrm{T}_{16}(50 \%$ Vermicompost $+50 \%$ Jeevamrutha + Gluconacetobacter diazotrophicus + Bacillus megaterium + Piriformospora indica+ Pseudomonas fluorescens + Bacillus subtilis + Trichoderma harzianum recorded more number of cobs (2.74), cob length (with husk $(22.45 \mathrm{~cm})$ and without husk $(11.43 \mathrm{~cm})$, cob girth (with husk $(8.50 \mathrm{~cm})$ and without husk $(5.89 \mathrm{~cm})$, weight of cobs (with husk (79.33 g) and without husk $(36.33 \mathrm{~g}))$ compared to other triplicate and individual inoculated treatment.

Our present research were similarly with Thavaprakash et al., (2005) who reported that substitution of 50 per cent NPK through goat or poultry manures along with Azospirillum and phosphobacteria had significant influence on all the growth and cob and yield parameters and also fresh cob and green fodder yield of baby corn.

At harvest higher plant biomass was $161.76 \mathrm{~g}$ plant $^{-1}$ was recorded in $T_{16}$ received with multiple inoculation of microbial and organic formulations followed by $\mathrm{T}_{14}$ (157.67 $\mathrm{g}_{\text {plant }}{ }^{-}$ $\left.{ }^{1}\right)$ Triple inoculation of microbial and organic formulations which were on par with each other. Lower biological plant biomass (101.90 $\mathrm{g}$ plant $^{-1}$ ) was recorded in control. The increase in plant biomass may be due to increased mobilization of nutrient to the plants by the inoculated microorganisms which may led to the accumulation of photosynthates in plant system.

\section{Nutrient content $(\%)$}

The significantly highest nitrogen content in baby corn plant was recorded in the treatment 
$\mathrm{T}_{12}(2.60 \%)$ and which significantly higher than other treatments followed by $\mathrm{T}_{14}(50 \%$ Vermicompost $+50 \%$ Jeevamrutha + Gluconacetobacter diazotrophicus + Bacillus megaterium + Piriformospora indica) (2.41 $\%)$ and $\mathrm{T}_{13}(50 \%$ Vermicompost $+50 \%$ Jeevamrutha + Trichoderma harzianum) and $\mathrm{T}_{15}(2.30$ and $2.38 \%)$ were on par with each other. The lowest nitrogen content (\%) was recorded in uninoculated control treatment $(1.01 \%)$.

\section{Phosphorus (\%)}

The phosphorus content in the baby corn plant was found to be highest in the treatment $\mathrm{T}_{16}$ $(0.68 \%)$ followed by $\mathrm{T}_{14}$ and $\mathrm{T}_{15}(0.66 \%$ and $0.62 \%)$, while significantly lowest phosphrous content $(\%)$ was recorded in the control $(0.15 \%)$.

\section{Potassium (\%)}

The highest potassium content was found to be maximum in $\mathrm{T}_{16}(1.17 \%)$ followed by $\mathrm{T}_{15}$ $(1.13 \%), \mathrm{T}_{16}(50 \%$ Vermicompost $+50 \%$ Jeevamrutha + Gluconacetobacter diazotrophicus + Bacillus megaterium + Piriformospora indica + Pseudomonas fluorescens + Bacillus subtilis + Trichoderma harzianum) which were on par with $\mathrm{T}_{14}(50 \%$ Vermicompost + 50\% Jeevamrutha + Gluconacetobacter diazotrophicus + Bacillus megaterium + Piriformospora indica) on par with $\mathrm{T}_{15}, \mathrm{~T}_{15}$ (Vermicompost, Jeevamrutha + Pseudomonas fluorescens+ Bacillus subtili, Trichoderma harzianum) and $\mathrm{T}_{7} \quad(25 \%$ Vermicompost $+25 \%$ jeevamrutha $+50 \%$ RDF) which were on par with each other. $\mathrm{T}_{6}$ $(50 \%$ Jeevamrutha $+50 \%$ RDF). Significantly lowest potassium content was recorded in the control $(0.70 \%)$.

The positive influence of integrated use of vermicompost and biofertilizers inoculation in $\mathrm{N}, \mathrm{P}$ and $\mathrm{K}$ status of plant parts seems to be due to their increased availability from soil. Moreover, higher photosynthetic activity in plant as evident from increase in biomass accumulation at successive growth stages and plant height reveals higher availability of metabolites from plant. This might have promoted growth of roots as well as their functional activity resulting in higher extraction of nutrients from plant 1 parts. The results of the present investigation strongly support the findings (Wu et al., 2005). The treatments which were studied in pot culture experiment under greenhouse condition were taken for further studied in field condition to check the efficiency of microbial and organic formulations on growth and yield parameters of baby corn (Zea mays L.)

\section{Acknowledgments}

Thankful to the Authors and Department of Agricultural Microbiology, University of Agriculture sciences, Bengaluru - 500065 India, for providing the necessary facilities in accomplishing the research work.

\section{References}

Amanda S., 2016, Molecular and biochemical characterization of endophytic bacteria associated with aerobic rice and their role in plant growth. Ph.D thesis UAS, Bengaluru India.

Anonymous, 2008, Definition of organic agriculture.

Devakumar, N., Rao, G. G. E. and Shuba, S., 2011, Evaluation of locally available media for the growth and development of nitrogen fixing micro- organisms. Proceedings of the third scientific conference of ISOFAR. Organic is life knowledge for tomorrow, held on $28^{\text {th }}$ September to $1^{\text {st }}$ October 2011, Korea. PP. 504-509.

Fletcher, R. A., Kallumbil, V. and Steele, P., 1982, An improved bioassay for 
cytokinins using cucumber cotyledons. Plant Physiol., 69: 675-677.

Gardner, F. P., Pearce, R. B and Mitchell, R. L., 1988, Physiology of crop plants. Pp. 242.

Jackson, M. L., 1973, Soil chemical analysis. Pub: Asia Publishing house, New Delhi, pp.468-469.

Karnwal, A., 2009, Production of Indol acetic acid by fluorescent Pseudomonas in the presence of L-Tryptophan and Rice root exudates. J Plant Pathol, 91: 61-63.

Kloepper, J. W. and Schroth, M. N., 1986, Plant growth-promoting rhizobacteria on radishes. In: Proc. of the $4^{\text {th }}$ International Conference on Plant Pathogenic Bacteria. Station de Pathologie Vegetaleet Phyto bacteriologie, INRA, Angers, France., 2: pp. 879-882.

Mai, M. D., 2004, Effect of Organic manures and biofertilizers on yield and quality of cucumber (Cucumis sativus L.) cv. Himangi, M.Sc. (Agri.) Thesis is submitted to MPKV, Rahuri.

Nanthakumar, S. and Veeraraghavathatham, D., 2000, Effect of Integrated nutrient management on growth parameters yield of brinjal (Solanym melongena L.) cv. PLR-1. South Indian Hortic., 48 (16) : 31-35.

Palekar, S., 2005, Shoonya bandavala dali naisargika krushi, published by Swamy Anand, Agri Prakashana., Bangalore, India.

Ponmurugan, P. and Gopi, C., 2006, In vitro production of growth regulators and phosphatase activity by phosphate solubilizing bacteria. African $J$. Biotechnol., 5: 348-350.

Pradeep, K., Yogesh, K. and Akhilesh, S., 2004, Baby corn - A potential crop, Intensive Agric., 3-9.

Rudresh, S., 2004, Effect of a combined inoculation of Rhizobium, a phosphate solubilizing Bacillus megaterium sub sp. phospaticum strain-PB and a biocontrol fungus Trichoderma spp. World J. Microbiol. Biotechnol., 21:7080.

Thavaprakash, N., Velayudham, K. and Muthukumar, V. B., 2005, Effect of crop geometry, intercropping system and integrated nutrient management practices on productivity of baby corn (Zea mays L.) based intercropping systems. Res. J. Agric and Biolo. Sci., 1(4):295-302.

Vadiraj, B. A., Siddagangaiah, S. N and Pottay, S. N., 1998, Response of coriander (Coriandrum sativum L.) cultivars to graded levels of vermicompost. J. Spices Arom. Crops., 7: $141-143$.

Wange, S. S. and Kale, R. H., 2004, Effect of bio-fertilizers under graded nitrogen levels on brinjal crop. J. Soils and Crops., 14 (1): 9-11.

Wu, S. C., Cao, Z. H., Li, Z. G., Cheung K. C. and Wong, M. H., 2005, Effects of biofertilizer containing $\mathrm{N}$ fixer, $\mathrm{P}$ and $\mathrm{K}$ solubilizers and AM fungi on main growth: a greenhouse trial. Elsevier, 125: $155-166$.

\section{How to cite this article:}

Latha, B., M.K. Shivaprakash, N. Devakumar and Mallikarjuna, N. 2018. Evaluation and Effect of Microbial Inoculants for Production of Growth Hormones and Organic Formulations on Growth of Baby Corn (Zea mays L.) under Green House Condition. Int.J.Curr.Microbiol.App.Sci. 7(10): 2167-2179. doi: https://doi.org/10.20546/ijcmas.2018.710.249 